\title{
Measurement of the Level of Nitric Oxide in Exhaled Air in Patients Using Acrylic Complete Dentures and with Oral Pathologies
}

\author{
Magdalena Wyszyńska 1,* , Aleksandra Czelakowska ${ }^{1}$, Rafał Rój ${ }^{1}$, Magdalena Zając ${ }^{2,3}$, Michał Mielnik ${ }^{4}$, \\ Jacek Kasperski ${ }^{1}$ and Małgorzata Skucha-Nowak ${ }^{5}$ (D)
}

1 Department/Institute of Prosthetic Dentistry and Dental Material Sciences, Medical University of Silesia in Katowice, ul. Poniatowskiego 15, 40-055 Katowice, Poland; aczelakowska@op.pl (A.C.); rafstoma@gmail.com (R.R.); protstom@sum.edu.pl (J.K.)

2 European Center for Diagnosis and Treatment of Urticaria (GA2LEN UCARE), Zabrze, Medical University of Silesia, ul. Poniatowskiego 15, 40-055 Katowice, Poland; magdalenazajac2000@gmail.com

3 Wroclaw Medical University, ul. Wybrzeże L. Pasteura 1, 50-367 Wroclaw, Poland

4 Department of Trauma and Orthopaedics, District Trauma and Orthopaedic Hospital, ul. Bytomska 62, 41-940 Piekary Śląskie, Poland; mmielnik@poczta.onet.pl

5 Department of Conservative Dentistry with Endodontics, Unit of Dental Propedeutics, Division of Medical Sciences in Zabrze, Medical University of Silesia inKatowice, ul. Poniatowskiego 15, 40-055 Katowice, Poland; mskucha-nowak@sum.edu.pl

* Correspondence: magdalena.wyszynska@sum.edu.pl

\section{check for}

updates

Citation: Wyszyńska, M.; Czelakowska, A.; Rój, R.; Zając, M.; Mielnik, M.; Kasperski, J.; Skucha-Nowak, M. Measurement of the Level of Nitric Oxide in Exhaled Air in Patients Using Acrylic Complete Dentures and with Oral Pathologies. Coatings 2021, 11, 169. https://doi.org/10.3390/coatings 11020169

\section{Academic Editor:}

Monika Lukomska-Szymanska

Received: 4 January 2021

Accepted: 28 January 2021

Published: 31 January 2021

Publisher's Note: MDPI stays neutral with regard to jurisdictional claims in published maps and institutional affiliations.

Copyright: (c) 2021 by the authors. Licensee MDPI, Basel, Switzerland. This article is an open access article distributed under the terms and conditions of the Creative Commons Attribution (CC BY) license (https:/ / creativecommons.org/licenses/by/ $4.0 /)$
Abstract: The measurement of nitric oxide (NO) in exhaled air is used in diagnostics and monitoring of the pathologies in the respiratory system but also in the oral cavity. Researchers have shown a huge increase of its level in asthma and diseases in the oral cavity. It seems reasonable to research the impact of pathologies in the oral cavity on the level of NO in exhaled air. The purpose of this study was to determine the impact of inflammation in the oral cavity (according to the material of dentures) on the level of nitric oxide in exhaled air. Three groups of patients were examined in this study. The hygiene of acrylic dentures, hard tissues, periodontal tissues, hygiene of the oral cavity, and level of NO in exhaled air were examined. Prosthetic stomatitis, denture plaque, tooth decay, poor sanitation and periodontitis increase levels of NO.

Keywords: acrylic denture; nitric oxide; Niox Mino; tooth decay; prosthetic stomatitis; periodontitis

\section{Introduction}

In the etiology of oral cavity pathologies, the main impact is from dental plaque, which in cases of a poor hygiene shows adhesion to hard tissues, soft tissues and acrylic dentures. Tooth decay, one of the most common oral diseases, is another pathology associated with dental plaque. It is described as a pathological process in which bacteria release substances or secondary metabolites that stimulate cells in the oral cavity to produce cytokines which lead to local disease such as gingivitis, mucositis, and periodontitis. This chronic inflammation can lead to systemic diseases-for example endocarditis [1-3].

Tooth decay is an infectious disease generated by Gram-positive and Gram-negative oral microorganisms located on the teeth surface. The colonisation of patogenic microflora or its' compounds such as LPS (lipopolysaccharide) and LTA (lipoteichoic acid) activates the cells of the immune systemie in the dental pulp complex. The binding of LPS and LTA to receptors on the surface of the cells of the dental pulp triggers signaling cascades finally activating the redox-sensitive transcription factor $\mathrm{NF}_{-\mathrm{k}} \mathrm{B}$ (nuclearfactor- ${ }_{\mathrm{k}} \mathrm{B}$ ). As a result, pro- or anti- inflammatory cytokines are produced and released. In turn, $\mathrm{NF}_{-\mathrm{k}} \mathrm{B}$ transcripts for the iNOS and interactions of methacrylates with cells of the oral cavity [4-6].

Periodontal disease occurs due to the imbalance between microorganisms in the dental plaque and the defence mechanisms of the host. Periodontitis is a group of chronic diseases 
that manifest themselves clinically with gingival erythema, bleeding after probing, the presence of periodontal pockets due to the loss of epithelial attachment and the loss of the alveolar bone visible in a radiological examination. Periodontitis is related to imbalance between the inflammatory response of the host and infection caused by Gram-negative bacteria. Bacteria that is present in the plaque cause the destruction of periodontal tissue through the release of toxins. The activity of enzymes, toxins, and metabolic products causes immediate initial destruction of periodontal tissue. And intermediate mechanism is also initiated. The natural response (chemotaxis, antigen opsonisation, phagocytosis) and acquired immunity (humoral and cell-mediated) are disrupted [7-12].

Keeping proper hygiene is also very important among edentulous patients using acrylic removable dentures. Poor hygiene leads to the formation of a denture plaque on its surface very fast. There is an indisputable relationship between denture plaque and inflammation of the prosthetic's base oral mucosa. The acrylic plate of the denture, especially the upper one, covers a big part of oral mucosa on the palatal side. It is very wet, and has a higher temperature, and there is no way to clean it by saliva. All those factors contribute to denture plaque and the colonisation of bacteria and candida. The usage of acrylic dentures is associated with an increased frequency of mycositis (mainly under the denture plate 95.5\%) usually from Candida spp. and Torulopsis spp. The pathologies of oral mucosa associated with the usage of acrylic dentures are called prosthetic stomatopathies. These different clinical and histopathological changes with different etiologies are mostly chronic atrophic or hypertrophic mucositis.

Diagnostics of systemic diseases employs most frequently blood and urine tests and histopathology, whereas the measurement of NO in exhaled air is less common. The advantages of this test are its noninvasiveness and quick results. The simplification of $\mathrm{NO}$ detection methods and the increasing number of reports suggesting its participation in many functions of the respiratory system have significantly increased interest in the measurement of NO in exhaled air. NO is a colourless inorganic gas synthesised from L-arginine in a process where L-arginine is catalysed to L-citrulline and NO by nitric oxide synthases (NOSs). The NO molecule has a free radical structure and by reacting with oxygen creates $\mathrm{NO}_{2}$ (nitrogen dioxide) radicals, and this is a mechanism of formation of reactive nitrogen species (RNS). The RNS obtained from the reaction between $\mathrm{NO}$ and superoxide anion $\left(\mathrm{O}_{2}{ }^{\bullet-}\right)$ is called peroxynitrite $\left(\mathrm{ONOO}^{-}\right)$, which undergoes protonation creating peroxynitrous acid. This acid is decomposed and creates strong oxidising agents: $\mathrm{NO}_{2}$ and $\mathrm{O}_{2}{ }^{\bullet-}$. NO is produced in the body by three different nitric oxide synthases (NOS) - two constitutive: neuronal (nNOS-NOS I) and endothelial (eNOS-NOS III), as well as the inducible synthase (iNOS-NOS II), which is mostly stimulated by cytokines and lipopolysaccharides. The deficiency of NO is present in many diseases of cardiovascular, gastrointestinal, genitourinary, and respiratory systems. In certain conditions excessive NOS expression, more precisely its inducible form, can prove disadvantageous for the body, as in septic shock. The constant exposure of cells to a high concentration of NO can have a cytotoxic effect causing damage to many organs. Under physiological conditions NO represents a neurotransmitter in the central nervous system; It is formed in endothelial cells and acts as a regulator of blood flow and pressure by affecting vascular smooth muscle. Under pathological conditions, such as inflammation, NO forms with the participation of the iNOS in a constant manner throughout many hours or even days. Excessive cyclooxygenase (COX-2) activation caused by this process can lead to the formation of large quantities of prion-flammatory prostaglandins and reactive oxygen species. Thus, excessive vasodilation can occur, which can cause the formation of oedema [13-16].

Pathological processes in the oral cavity, such as dental caries, periodontitis or mucositis are related to the use of prosthetic restorations, in which mainly gingival fibroblasts and pulp cells are responsible for a systemic reaction to the infection. In this process blood cells (neutrophils, monocytes) and vascular endothelial cells activated by antigens (bacteria, viruses, parasites, carcinogens) release pro-inflammatory mediators, whose overexpression causes tissue damage. These mediators include numerous cytokines, such as interleukins: 
IL-1beta, IL-2, IL-6, TNF-alpha (Tumor Necrosis Factor alpha), and IFN- $\gamma$ (gamma interferon), which stimulate white blood cells, primarily macrophages, to produce large amounts of NO through iNOS. The induction of xanthine oxidase (XAO) and NADPH oxidase (nicotinamide dinucleotide phosphate oxidase) occurs at the same time and the formed superoxide anion radical releases selectin activators from mast cells (histamine, thrombin), facilitating the initial contact of leukocytes with endothelial cells and the process of leukocyte rolling along the vessels. NO also limits the degranulation of mast cells located near microcirculation vessels, which are the source of pro-inflammatory mediators. This means that $\mathrm{NO}$ controls the initial stage of inflammation development, whose later progressing character can lead to tissue damage [17-19].

The measurement of NO in exhaled air is applicable in the diagnostics and monitoring of patients with inflammations in the oral cavity, respiratory tract and the digestive system. The measurement of NO in exhaled air is a simple non-invasive and patient-friendly diagnostic tool, which is useful in patients suffering from bronchial asthma. The test is easy for the patient and renders prompt results. NO in exhaled air is an indication of inflammatory process and responds quickly to treatment or exacerbation of the disease. Ziettkowski et al. demonstrated the superiority of measuring the NO in exhaled air over conventional tests recommended in the diagnostics and monitoring of asthma patients. Therefore, it is justified to conduct studies evaluating the influence of various pathological processes in the oral cavity on the concentration of $\mathrm{NO}$ in exhaled air. Foundations presented here- the evaluation of the concentration of NO in exhaled air in patients with severe dental caries, periodontitis, and using full dental restorations-have not been the subject of any scientific analyses [20-24].

\section{Materials and Methods}

The study included three groups of patients who reported for making new dentures, control, or dental consultation. The examination took place during one visit in NZOZ Akademickie Centrum Stomatologii Sp. z o.o., Plac Akademicki, Bytom, Poland in the Outpatient Clinic of Prosthetic Dentistry and Dental Surgery. The study group consisted of 100 patients with severe carious process, not using prosthetic restorations, aged 25-65; 100 patients using upper and lower full dentures, aged 25-85; the control group consisted of 30 patients with no prosthetic restorations, no carious process, and with proper oral hygiene. Only generally healthy patients were qualified for the study. The performance of dental examination required basic dental instruments, consisting of a mirror, an explorer, and a periodontal probe. The concentration of NO in exhaled air was measured with the Niox Mino ${ }^{\circledR}$ sensor (Aerocrine AB, Solna, Sweden). Furthermore, patients were tested according to a survey designed for the purpose of this study. All participants were informed about the purpose and principles of the study, to which they consented in writing. A positive opinion of the Bioethical Commission of the Medical University of Silesia in Katowice was obtained to perform the examinations (Resolution No KNW/0022/KB1/29/I/11 of 15 March 2011).

Exclusion criteria included general somatic diseases, the use of dentures for more than five years, smoking tobacco, chronic use of medicines, and no consent for participation in the study.

\subsection{Clinical Examination}

\subsubsection{Description of Indices}

Hard tooth tissue was examined with a mirror and an explorer with artificial lighting. $\mathrm{D}$ (D-number of teeth with primary and/or secondary caries, decayed), $\mathrm{M}(\mathrm{M}$-number of teeth removed due to caries, missing), $\mathrm{F}$ ( $\mathrm{F}$-number of filled teeth) and DMF numbers were calculated. The DMF index is the sum of D + M + F values. Although it does not provide information on the actual intensity of caries, this index is commonly used in epidemiological examinations for comparisons between populations. 
Periodontal examination was conducted with a dedicated probe with a spherical ending of $0.5 \mathrm{~mm}$ in diameter, which is compatible with the WHO standard. The Gingival Bleeding Index (GBI) according to Ainamo and Bay was used. The data were registered for specific quadrants and recorded separately for each of them: quadrants 1 and 3 from the side of the oral cavity proper, quadrants 2 and 4 from the side of the vestibule. The presence or absence of bleeding was measured by leading the periodontal probe along the gingival cavity, according to a 4-step scale: 0 -no bleeding from the gingival cavity within $30 \mathrm{~s}$, 1-bleeding within 3-30 s, 2-bleeding within 2 s, 3-immediate bleeding upon insertion of the probe.

The condition of oral hygiene was evaluated according to the Oral Hygiene Index (OHI) developed by Greene and Vermillion and the Plaque Index (PLI) developed by Silness and Löe. Plaque presence was established visually, using a mirror and an explorer.

$\mathrm{OHI}-\mathrm{Oral}$ Hygiene Index by Green and Vermillion consists of the Debris Index and the Calculus Index. The amount of deposit is examined on six surfaces of six teeth: buccal surfaces of teeth 16 and 26, lingual surfaces of teeth 36 and 46, labial surface of tooth 11 and lingual surface of tooth 31 . Evaluation criteria for debris and calculus are as follows: 0 -no debris or stain present, 1 -soft debris covering not more than $1 / 3$ of the tooth surface, or the presence of extrinsic stains without other debris regardless of surface area covered, 2 - soft debris covering more than $1 / 3$, but not more than $2 / 3$, of the exposed tooth surface, 3 -Soft debris covering more than $2 / 3$ of the exposed tooth surface $[25,26]$.

$\mathrm{OHI}=$ sum of all values/total number of the examined tooth surfaces

PLI-Plaque Index by Silness and Löe is used for evaluation of the accumulation of the dental plaque around dental cervix. The measurement is conducted on buccal, lingual and both occlusal surfaces of six teeth $(16,14,11,31,34,36)$. Evaluation criteria are as follows: 0 -clean teeth surfaces, no plaque, 1 - a film of plaque adhering to the free gingival margin and adjacent area of the tooth; the plaque may be seen in situ only after the application of disclosing solution or by using the probe on the tooth surface, 2-moderate accumulation of soft deposits within the gingival pocket, or the tooth and gingival margin which can be seen with the naked eye, 3-abundance of soft matter within the gingival pocket and/or on the tooth and gingival margin.

\section{PLI = sum of all values/total number of the examined tooth surfaces}

The mucous membrane was examined and classified in accordance to Newton's classification of denture-related stomatitis, as modified by Spiechowicz. Evaluation criteria are as follows: 0 -no lesions on the mucosa, presence of subjective ailments: burning, sharp pain, or dry mouth, 1-localised inflammatory lesions, most commonly around palatal salivary gland outlets, 2-diffuse inflammation of the oral mucosa covered by the denture, sometimes inflammatory oedema, 3-hypertrophic, papillary mucositis, usually on the central hard palate.

Cleanliness of the denture was evaluated according to the Budtz-Jørgensen index for plaque on full upper dentures. Interpretation of results: 0-no plaque observed after scraping with a dull instrument, 1 -plaque visible after scraping with a dull instrument, can be visible on the instrument, 2-moderate accumulation of plaque visible with naked eye, surface of the denture partially covered with visible debris, 3-abundant plaque, surface of the denture fully covered with visible debris.

Measurement of the concentration of $\mathrm{NO}$ in exhaled air was performed non-invasively with the Niox Mino ${ }^{\circledR}$ sensor (Aerocrine AB, Solna, Sweden) and consisted of inhalation of air from the device, followed by steady exhalation to the device. Results were obtained after two minutes on the screen of the device. Each patient received a disposable mouthpiece for the examination. 


\subsubsection{Description of the Measuring Device}

Niox Mino ${ }^{\circledR}$ (Aerocrine AB, Solna, Sweden) is a portable medical device for measuring fractional exhaled nitric oxide (FeNO), providing results in parts per billion (ppb-the number of NO particles in one billion gas particles, i.e., $1 \mathrm{ppb}$ is equal to $1 \mathrm{~nL} / \mathrm{L}$ ). The device meets all the requirements associated with the monitoring of NO, defined by the American Thoracic Society (ATS) and the European Respiratory Society (ERS). It employs the chemiluminescence method to measure the concentration of NO. NO reacts with ozone inside the analyser. The product of this reaction is $\mathrm{NO}_{2}$ with an electron in an excited state. During the transition to the basic energy state, electromagnetic radiation with waves between 600 and $3000 \mathrm{~nm}$ is emitted. The waves are detected by a photomultiplier and transformed into an electric signal. Chemiluminescence is a very sensitive measurement method-systems used in clinical examinations detect NO in the concentration of $\leq 1 \mathrm{ppb}$. The device is equipped with an NO filter (scrubber), which eliminates NO present in the atmosphere. NIOX Flow Control maintains the airflow rate during exhalation at the level of $50 \mathrm{~mL} / \mathrm{s}$ regardless of the patient's abilities. Each measurement is scrutinised, and an automatic test inspects the contour lines level. This ensures the recurrence and correctness of results. The so-called dead space is minimised in the device thanks to the use of unique filters and putting the sampling port as close to the mouth as possible [27-29].

\subsection{Statistical Analysis}

Study results presented here in represent quantitative (nitrogen concentration, age, number of teeth, etc.) and qualitative features (Newton's classification, Plaque Index, tobacco smoking, etc.). Quantitative features included continuous (nitrogen, OHI, PLI) and discrete (number of teeth, etc.) variables. Continuous variables were tested with the ShapiroWilk Normality Test. It was concluded that these variables demonstrate normal distribution, which enabled the application of parametric tests. Two samples were compared with the $t$-test if the variances were homogeneous or a test with separate estimation of variance if they were not. Three or more samples were compared with one-way ANOVA. Rejection of the hypothesis of equality of at least three averages allowed for multiple comparisons for each pair of all the compared averages, which was conducted with the Least Significant Difference (LSD) test. The assumption of homogeneity of variance was tested with Levene's test. In the case of no homogeneity of variance, the ANOVA and LSD tests were conducted for logarithmic values. Logarithmic transformation ensured the homogeneity of variance. Connections between the concentration of nitric oxide with OHI, PLI indices, and the number of teeth were tested with Spearman's rank-order correlation. Description of the data was presented for continuous variables as arithmetic mean and standard deviation. All applied tests were conducted on the level of significance $\alpha=0.05$ with use of Statistica software.

\section{Results}

\subsection{Results in the Group Using Upper and Lower Full Dentures}

\subsubsection{Evaluation of Mucositis}

In the study group the correlation between the condition of the mucosa and the average concentration of NO in exhaled air in patients with full dentures was evaluated. The highest concentration of NO in exhaled air was observed in patients with granulomatous hypertrophic oral mucositis (approximately $49 \mathrm{ppb}$ ). Low values of $\mathrm{NO}$ concentration (approximately $13 \mathrm{ppb}$ ) were observed in patients with no clinical symptoms of prosthetic stomatopathies (Figure 1). 


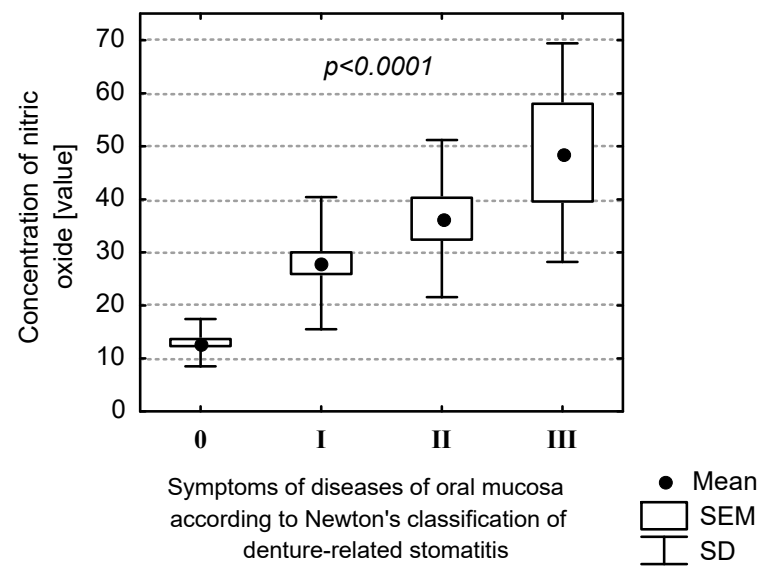

Figure 1. Correlation between average concentration of nitric oxide in exhaled air and the exacerbation of symptoms of diseases of oral mucosa according to Newton's classification of denturerelated stomatitis.

\subsubsection{Evaluation of Denture Hygiene}

In the study group, the correlation between denture hygiene and the average concentration of NO in exhaled air in patients with full dentures was evaluated. Denture plaque was not observed, or only very slight amounts of it were observed, in half of the patients in the study group.

A very high level of NO concentration (approximately $44 \mathrm{ppb}$ ) was observed in patients with improper denture hygiene. Patients with exemplary denture hygiene had between 8 and $14 \mathrm{ppb}$ of $\mathrm{NO}$ in exhaled air (Figure 2).

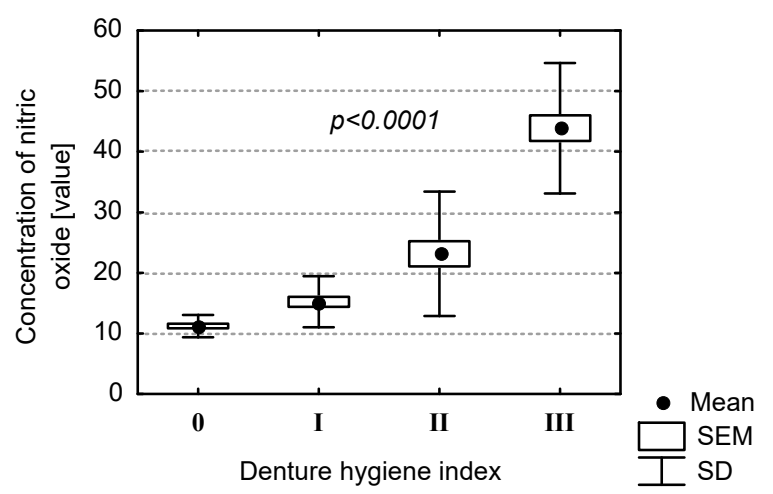

Figure 2. Correlation between average concentration of nitric oxide in exhaled air and denture hygiene.

3.1.3. Comparison of Denture Plaque Index and Oral Mucosa Condition Index with the Concentration of $\mathrm{NO}$

Denture plaque index and Newton's oral mucosa condition index were compared with the concentration of NO in exhaled air (Table 1).

A highly significant effect of the amount of plaque on the concentration of NO both in the case of no lesions of the mucosa $(p=0.0008)$ and with single erythemas $(p<0.0001)$ was demonstrated. The amount of plaque visible after scraping with an instrument (Index 1) with healthy mucosa increases NO concentration to a small extent (close to statistical significance, $p=0.0745$ ), whereas the influence of a moderate amount of plaque (Index 2) increases the excretion of NO significantly enough to make the difference between average NO concentrations highly statistically significant $(p=0.0002)$. Single erythemas of the mucosa were accompanied by the presence of plaque, whose influence proved significant with various NO averages for amount I and amount II $(p=0.0133)$ and highly significant for amount II and amount III $(p<0.0001)$. By a small amount of denture plaque, single erythemas caused a statistically significant $(p=0.0062)$ increase of NO concentration, 
while for a moderate amount of denture plaque, the difference in the average level of $\mathrm{NO}$ concentration for Newton $=0$ and Newton $=\mathrm{I}$ was only close to statistical significance $(p=0.0760)$. An abundant amount of plaque (Index 3) influences the secretion of NO to such an extent that inflammatory changes of the mucosa do not have a statistically significant influence on the concentration of $\mathrm{NO}$ in exhaled air.

Table 1. Comparative analysis of the influence of denture plaque index and Newton's oral mucosa condition index on the concentration of NO in exhaled air.

\begin{tabular}{|c|c|c|c|c|c|c|}
\hline \multicolumn{6}{|c|}{ Newton's Classification of Denture Stomatitis } & \multirow{2}{*}{ Test $\mathbf{t}(p)$} \\
\hline \multicolumn{2}{|c|}{ Denture Plaque Index } & 0 & I & II & III & \\
\hline \multicolumn{2}{|l|}{0} & $\begin{array}{c}11.2 \pm 1.8 \\
(25)\end{array}$ & & - & - & - \\
\hline \multicolumn{2}{|l|}{1} & $\begin{array}{l}13.2 \pm 2.9 \\
\quad(11)\end{array}$ & $\begin{array}{l}17.8 \pm 4.1 \\
\quad(12)\end{array}$ & - & - & 0.0062 \\
\hline \multicolumn{2}{|l|}{2} & $\begin{array}{l}18.1 \pm 7.5 \\
(8)\end{array}$ & $\begin{array}{c}26.1 \pm 10.6 \\
(14)\end{array}$ & - & - & 0.0760 \\
\hline \multicolumn{2}{|l|}{3} & - & $\begin{array}{l}41.5 \pm 7.8 \\
\quad(11)\end{array}$ & $\begin{array}{l}44.1 \pm 6.7 \\
\quad(10)\end{array}$ & $\begin{array}{c}48.8 \pm 20.1 \\
(5)\end{array}$ & 0.4662 \\
\hline \multicolumn{2}{|c|}{${ }^{*} \operatorname{ANOVA}(p)$} & 0.0008 & $<0.0001$ & & & \\
\hline \multirow{5}{*}{$\begin{array}{l}\text { LSD test }(p) \text { for the } \\
\text { compared pairs: }\end{array}$} & 0.1 & 0.0745 & - & & & \\
\hline & 0.2 & 0.0002 & - & & & \\
\hline & 1.2 & 0.0406 & 0.0133 & & & \\
\hline & 1.3 & - & $<0.0001$ & & & \\
\hline & 2.3 & - & $<0.0001$ & & & \\
\hline
\end{tabular}

* ANOVA-analysis of variance, extension of $\mathrm{t}$ - and $\mathrm{z}$-tests.

\subsection{Results in a Group of Patients with Tooth Decay}

\subsubsection{Evaluation of the DMF Index}

The value of the intensity of caries in the study group was between 15 and 29 $(20.57 \pm 2.92)$ and between 4 and $14(8.13 \pm 3.01)$ in the control group. In the study group, the correlation between the DMF number and the concentration of nitric oxide in exhaled air was evaluated. The analysis demonstrated that the D number (13.74 \pm 3.32 vs. 0$)$ has the largest influence on the level of concentration of NO in exhaled air. Among patients with high D numbers (13.74 \pm 3.32$)$, meaning a large number of carious foci, the value of nitric oxide concentration was relatively high. Among patients with no active carious foci the level of NO concentration in exhaled air was normal. Patients with high F numbers $(2.11 \pm 1.74$ vs. $8.03 \pm 2.96)$, which is evidence of increased care for the elimination of inflammatory foci, demonstrated low levels of $\mathrm{NO}$ concentration in exhaled air.

The concentration of NO in exhaled air in patients with severe carious process was on average $32 \mathrm{ppb}$, whereas in the control group including patients with no carious foci the level of the concentration was significantly lower at $14 \mathrm{ppb}$ on average. Comparison of the study group with the control group is presented in Figure 3. 


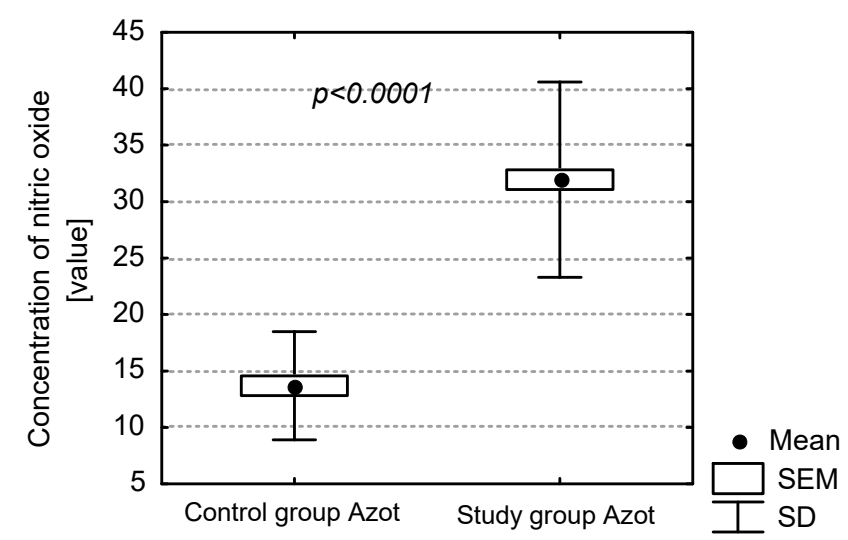

Figure 3. Comparison of the average level of NO concentration in exhaled air between the study and control groups.

\subsubsection{Evaluation of the GBI}

Value of the GBI in the study group was between 0.01 and $1.42(0.59 \pm 0.37)$ and between 0 and $0.53(0.11 \pm 0.16)$ in the control group. Correlation between periodontal health based on the GBI and the concentration of NO in exhaled air was also evaluated. Clinical state of the periodontium was evaluated on the basis of the GBI, since bleeding from the periodontal pocket is the first symptom of periodontitis. Comparison of the values of GBI in study and control groups is presented in Figure 4. Among patients with exacerbated gingival bleeding, the values of GBI were high. Among patients with no gingival bleeding during examination, the values were low. Value of the concentration of $\mathrm{NO}$ in exhaled air increases with the exacerbation of bleeding from the gingival pocket.

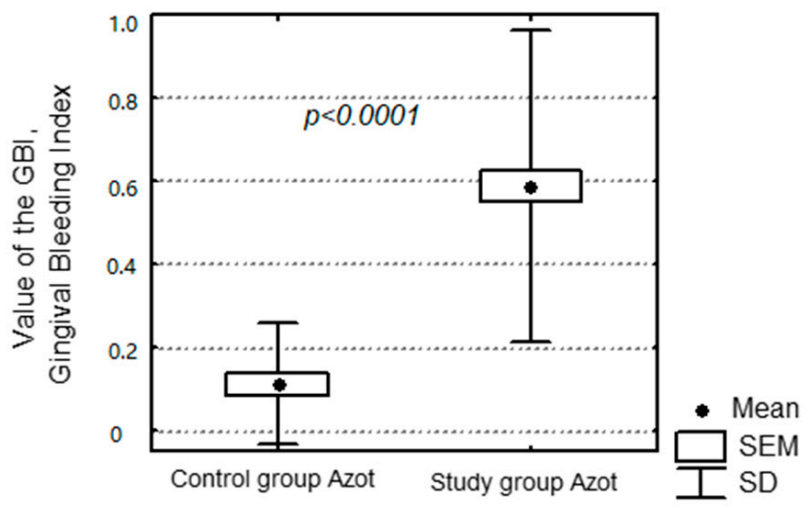

Figure 4. Comparison of the values of Gingival Bleeding Index (GBI) in study and control groups.

\subsubsection{Evaluation of the $\mathrm{OHI}$}

Value of the $\mathrm{OHI}$ in the study group was between 0.83 and $3(2.15 \pm 0.46)$ and between 0 and $0.83(0.34 \pm 0.22)$ in the control group. The condition of oral hygiene in dentulous patients was evaluated on the basis of the OHI-S and the PLI. Values of the OHI-S and the PLI were significantly higher in the study group compared to the control group as illustrated in Figure 5. 


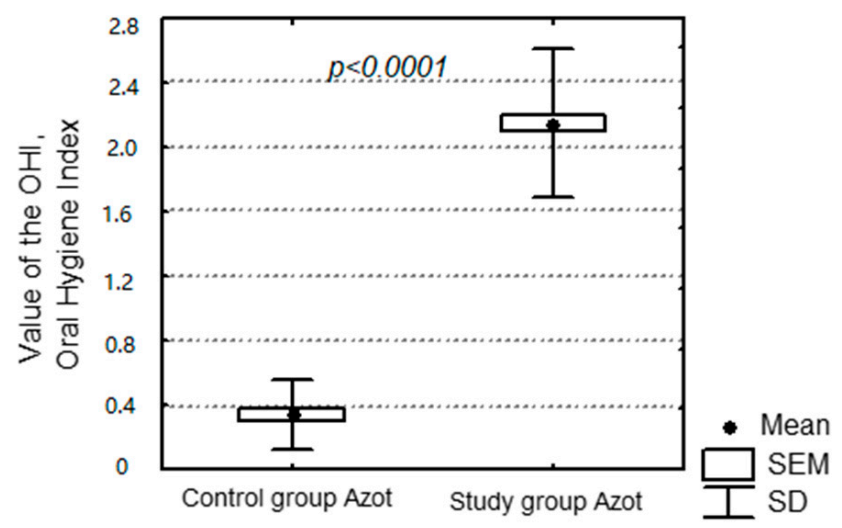

Figure 5. Comparison of the values of Oral Hygiene Index (OHI)-S in study and control groups.

\subsubsection{Evaluation of the PLI}

The value range of the PLI was $0.06-3.00(2.11 \pm 0.45)$ in the study group and between $0.04-0.54(0.21 \pm 0.15)$ in the control group. Correlation between oral hygiene and the concentration of $\mathrm{NO}$ in exhaled air was evaluated in the study group. A statistically significant influence of the lack of proper oral hygiene and abundant plaque on the concentration of NO in exhaled air was demonstrated. Values of PLI were higher in the study group compared to the control group, as illustrated in Figure 6.

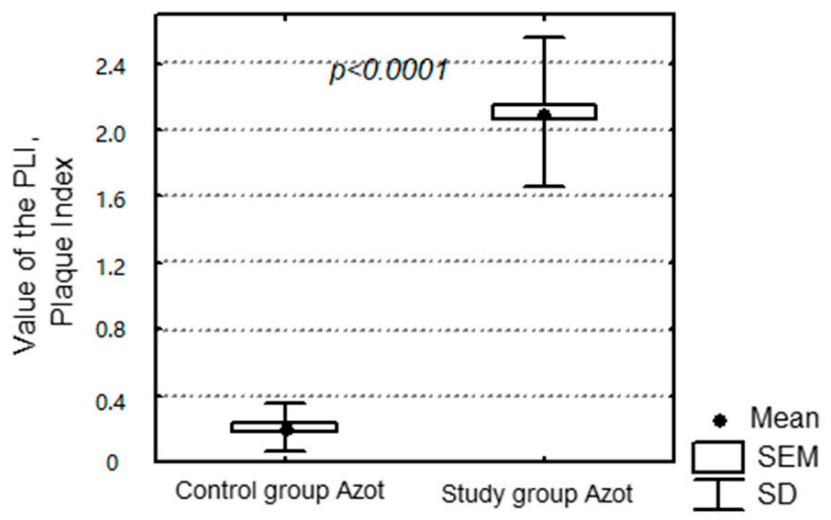

Figure 6. Comparison of the values of Plaque Index (PLI) in study and control groups.

\section{Discussion}

In the last 15 years; a new method of monitoring the inflammatory process within lungs - evaluation of the concentration of NO in exhaled air-has become popular. It is particularly significant in the treatment of bronchial asthma. The increase of NO concentration is associated with the exacerbation of inflammation, and its decrease is connected with antiphlogistic treatment used in asthma. Therefore, it is the recommended method for monitoring the course of this disease. Changes in the concentration of NO in exhaled air are not a phenomenon specific for asthma. They are also observed in different diseases, such as allergic rhinitis, eosinophilic bronchitis, Churg-Strauss syndrome, in atopic persons, and in sleep-disordered breathing [30-32]. Normally functioning oesophageal sphincters should protect from NO from the digestive tract. So far, the influence of digestive tract disorders on the measurement of concentration of NO in exhaled air has not been described. The determination of such a correlation is very important, since the increase of NO concentration resulting from digestive tract disorders may imply faulty therapeutic decisions in patients with bronchial asthma $[33,34]$. Therefore, it seems advisable to determine the concentration of NO in patients with inflammation within their own dentition and oral mucositis.

Measurement of the concentration of NO in exhaled air is considered to be a noninvasive examination of inflammation. As demonstrated in our own study, the presence 
of dental caries, periodontitis and insufficient oral hygiene have a large influence on the concentration of NO in exhaled air. This correlation has also been demonstrated in edentulous patients. The condition of denture hygiene and mucous membrane of prosthetic medium significantly influences the determination of inflammatory markers in the air. Among edentulous patients, teeth with active carious foci have a crucial influence on the concentration of NO in exhaled air. This may be a result of patients with dental caries having numerous strains of aerobic and anaerobic bacteria, the presence of which increases the concentration of inflammatory markers. In the case of patients with satisfactory oral hygiene and thus a higher number of filled teeth (F number), the concentration of $\mathrm{NO}$ was relatively low.

Oral hygiene was also examined with basic hygiene indices-i.e., the PLI and the simplified OHI-S. Values of the OHI-S and the PLI were significantly higher in the study group compared to the control group. Values of NO in exhaled air were significantly higher among patients with unsatisfactory oral hygiene. Condition of the periodontium also influenced the level of exhaled NO. This group of patients exhibited a significantly higher level of NO in exhaled air. The factors increasing the concentration of NO in edentulous patients were periodontitis and bad oral hygiene. Both these elements are closely related, since bad oral hygiene directly influences the formation of dental plaque, which leads to an accumulation of dental calculus if not removed. This results in gingivitis, intensified gingival bleeding and consequently chronic periodontitis.

In the group of edentulous patients with full prosthetic restorations the level of concentration of $\mathrm{NO}$ is relatively higher in case of failure to follow the rules of denture hygiene. Patients with full dentures covered with abundant amounts of denture plaque exhaled air with a significantly increased concentration of NO. It is most probably the result of the lack of denture hygiene promoting the accumulation of plaque on them, and thus the formation of an inflammatory process, which is responsible for the increase of concentration of NO. Apart from denture hygiene, the clinical condition of mucosa and its influence on the level of discussed inflammatory marker were analysed. Different degrees of intensity of the inflammation were observed in the patients, varying from healthy mucosa, through single erythemas, to hypertrophic granulomatous inflammation. The degree of intensity of prosthetic stomatopathies resulted in the increase of the level of NO in exhaled air, but it was the denture hygiene condition that was the factor most significantly influencing the discussed inflammatory marker. It was observed that denture hygiene was improper in patients with advanced stomatopathy. In the group of patients with type 3 stomatitis according to Newton and bad denture hygiene the level of concentration of $\mathrm{NO}$ was the highest (approximatelt 50-60 ppb). Poor hygiene of acrylic dentures consequently provides the colonisation of denture plaque. This is a straight way to inflammation of the mucosa under the surface of the denture. Warm, wet, with no air flow, and with denture plaque facilitates the inflammatory process.

NO has so far been mostly used in diagnostics and monitoring of bronchial asthma. Clinical studies have demonstrated that the concentration of NO in exhaled air is significantly higher in patients suffering from bronchial asthma than in the healthy population. NO metabolites can play a role in the pathogenesis of chronic sinusitis. An increased amount of exhaled NO and its metabolites occurs in chronic sinusitis, suggesting the participation of these compounds in the pathogenesis of the chronic sinusitis [35]. Apart from respiratory system disorders, the influence of digestive tract disorders on the concentration of NO in exhaled air seems to be particularly interesting. Dor-Wojnarowska et al. studied the influence of oesophageal inflammation on the concentration of NO in exhaled air [36]. The study did not demonstrate a significant influence of chronic digestive tract inflammation on the level of concentration of NO in exhaled air. The digestive tract, similarly to paranasal sinuses, is a reservoir with a significantly higher concentration of NO than respiratory tracts. The lack of influence of digestive tract disorders on the concentration of NO in exhaled air is most probably caused by positive intrathoracic pressure, which prevents the passage of $\mathrm{NO}$ during exhalation. The level of concentration of $\mathrm{NO}$ was also 
investigated by Przybyłowski et al. They studied NO in exhaled air in patients with obstructive sleep apnoea (OSA). Their most significant observation was that the concentration of NO in exhaled air in patients with sleep apnoea is much higher than in persons without sleep-disordered breathing. It is most probably caused by the development of respiratory inflammation in patients with sleep apnoea [37].

The concentration level of NO in exhaled air as a diagnostic method has not been a subject of research in the field of dentistry. As shown in the literature, the concentration level of NO was studied in saliva preparations, gingival crevicular fluid, a segment of inflamed mucosa, and tissue specimen from the mass of the tumour. Vanessa G.S. Reher et al. studied the level of $\mathrm{NO}$ in saliva in patients with exacerbated chronic periodontitis. They measured the concentration of $\mathrm{NO}$ and compared patients with exacerbated chronic periodontitis with persons free from inflammations. Measurement of the concentration of NO in saliva was performed with the Griess test. Solution of $1 \%$ sulphonamide and $0.1 \%$ solution of $0.1 \%$ naphthylethylenediamine with $5 \%$ orthophosphoric acid were prepared. The Griess solution reacts with saliva, and if NO is present, it becomes purple. NO concentration was measured with the spectrophotometric method. Based on the conducted research, the authors concluded that the concentration of NO in saliva increases as the periodontitis develops. Patients with acute chronic periodontitis exhibit higher levels of NO than patients with generalised chronic periodontitis. Among those without inflammations the level of NO was lower [38]. An increase of NO synthesis in the case of periodontitis was also shown by Batista et al. They collected segments of mucous membrane during periodontal surgical procedures. The operated tissues were affected with chronic periodontitis. Concentration of NO was higher in a statistically significant way compared to the control group. Increase of NO synthesis is a response to the inflammation in soft tissues of the oral cavity and can have a positive effect as an inflammatory marker [39]. D.F. Lappin et al. collected segments of inflamed tissue, tested them immunohistochemically, and compared to samples of healthy tissue. The high level of NO in inflamed tissue is related to tissue damage and cell death. They demonstrated a clear role of $\mathrm{NO}$ in the initiation of immune response in case of a periodontal disease [40]. An increase in the concentration of NO is observed not only in chronic periodontitis. Shibata et al. observed an increase in NO level in localised aggressive periodontitis. Neutrophil function and chemotaxis are disrupted in this pathological process. Chemotaxis is related to NO and NOS. The authors examined the activity of nitric oxide synthase in aggressive periodontitis and its relation to chemotaxis [41]. Completely different results were shown by researchers from the University of Zagreb. Aurer et al. measured the amount of stable NO metabolite $\left(\mathrm{NO}_{2}{ }^{-}\right)$in saliva of patients with aggressive periodontitis and healthy persons. The authors' goal was to define the role played by NO in the development of periodontopathy. The Griess test was used to measure the concentration of NO in saliva. Patients with periodontitis had a lower level of $\mathrm{NO}_{2}{ }^{-}$in the saliva than patients with heathy periodontium [42]. A study of NO concentration in gingival tissues was also conducted by Hirose et al. Samples were collected from the base of gingival pocket and surface of the gingiva. Measured values were compared to the control group. The authors demonstrated in the study the increase of IL- 6 and NO concentration in periodontopaties. Inflammation of periodontal tissues, including gingiva, is initiated by the colonisation of pathogenic bacteria in the oral cavity. Cytokines and NO released from the inflammatory focus play a significant role in the initiation of immune response [43]. An increased level of NO was also demonstrated by Sapna Pajawani et al. They measured the concentration of NO in saliva in a group of patients with oral lichen planus (OLP). The study material was patients' saliva, in which the concentration of NO was determined according to the Griess test. High concentration of NO was demonstrated in groups with OLP [44]. Behçet's syndrome is similar in this respect to oral lichen planus. The purpose of the study by Yalçin İşcan et al. was to determine the role and level of NO and its metabolites in Behçet's syndrome. The authors showed a significantly higher level of NO in patients suffering from Behçet's syndrome according to the control group [45]. 
The measurement of NO in exhaled air is a valuable diagnostic method. It can be used in the monitoring of bronchial asthma and other general diseases. However, the evaluation of results in patients reporting to clinics and interpretation of the results of such examinations must take into consideration the coexistence of masticatory system disorders. The omission of dental examination and possible elimination of odontogenic outbreaks may affect the application of general diagnostic results and further treatment.

\section{Conclusions}

The presence of denture plaque significantly increased the concentration of NO in exhaled air in patients with full dentures.

A significant correlation between the occurrence of prosthetic stomatopathies and increased concentration of NO in exhaled air was demonstrated.

The study demonstrated the influence of carious foci on the increase in concentration of $\mathrm{NO}$ in exhaled air.

Bad oral hygiene and periodontitis influence the increase of NO concentration as an inflammatory marker.

Author Contributions: M.W., A.C., and J.K. conceived and designed the experiments; M.W., A.C., R.R., and J.K. performed clinical examinations; M.W., A.C., M.Z., M.M., J.K., and M.S.-N. analyzed the data; M.W., A.C., and M.S.-N. wrote the paper; M.W. and M.S.-N. performed editorial correction of the paper. All authors have read and agreed to the published version of the manuscript.

Funding: This research was funded by Śląski Uniwersytet Medyczny w Katowicach, research number: KNW-1-206/N/8/K.

Institutional Review Board Statement: In The study was conducted with the prior approval from the Bioethics Committee of the Medical University of Silesia in Katowice, Poland, Resolution No KNW/0022/KB1/29/I/11, 15th of March 2011.

Informed Consent Statement: Informed consent was obtained from all subjects involved in the study.

Conflicts of Interest: The authors declare no conflict of interest.

\section{References}

1. Ninomiya, M.; Hashimoto, M.; Yamanouchi, K.; Fukumura, Y.; Nagata, T.; Naruishi, K. Relationship of oral conditions to the incidence of infective endocarditis in periodontitis patients with valvular heart disease: A cross-sectional study. Clin. Oral Investig. 2020, 24, 833-840. [CrossRef] [PubMed]

2. Patrakka, O.; Pienimäki, J.P.; Tuomisto, S.; Ollikainen, J.; Lehtimäki, T.; Karhunen, P.J.; Martiskainen, M. Oral bacterial signatures in cerebral thrombi of patients with acute ischemic stroke treated with thrombectomy. J. Am. Heart Assoc. 2019, 8. [CrossRef] [PubMed]

3. Kriebel, K.; Hieke, C.; Müller-Hilke, B.; Nakata, M.; Kreikemeyer, B. Oral biofilms from symbiotic to pathogenic interactions and associated disease-connection of periodontitis and rheumatic arthritis by peptidylarginine deiminase. Front. Microbiol. 2018, 9, 53. [CrossRef]

4. Schweikl, H.; Birke, M.; Gallorini, M.; Petzel, C.; Bolay, C.; Waha, C.; Buchalla, W. HEMA-induced oxidative stress inhibits NF-кB nuclear translocation and TNF release from LTA-and LPS-stimulated immunocompetent cells. Dent. Mater. 2021, 37, 175-190. [CrossRef] [PubMed]

5. Barbadoro, P.; Ponzio, E.; Coccia, E.; Prospero, E.; Santarelli, A.; Rappelli, G.G.; D’Errico, M.M. Association between hypertension, oral microbiome and salivary nitric oxide: A case-control study. Nitric Oxide 2021, 106, 66-71. [CrossRef]

6. Schweikl, H.; Gallorini, M.; Pöschl, G.; Urmann, V.; Petzel, C.; Bolay, C.; Hiller, K.-A.; Cataldi, A.; Buchalla, W. Functions of transcription factors NF-_B and Nrf2 inthe inhibition of LPS-stimulated cytokine release by theresin monomer HEMA. Dent. Mater. 2018, 34, 1661-1678. [CrossRef]

7. Jańczuk, Z.; Banach, J. Choroby błony śluzowej jamy ustnej i przyzębia: Podręcznik dla studentów stomatologii. Wydaw. Lek. 2013, PZWL.

8. Yousefi, L.; Leylabadlo, H.E.; Pourlak, T.; Eslami, H.; Taghizadeh, S.; Ganbarov, K.; Yousefif, M.; Tanomandg, A.; Yousefi, B.; Kafil, H.S. Oral spirochetes: Pathogenic mechanisms in periodontal disease Microbial Pathogenesis. Microb. Pathog. $2020,144$. [CrossRef]

9. Kinane, D.F.; Stathopoulou, P.G.; Stathopoulou, P.N. Periodontal diseases. Nat. Rev. Dis. Primers 2017, 3, 17038. [CrossRef]

10. Saxena, S.; Gowd, S.; Shankar, T.; Suresan, V.; Mantri, S.; Mishra, P.; Panday, P. Denture hygiene knowledge and practices among complete denture wearers attending a postgraduate dental institute. J. Contemp. Dent. Pract. 2017, 18, 714-721. 
11. Paranhos, H.D.F.O.; Da Silva, C.H.L.; Venezian, G.C.; Macedo, L.D.; Souza, R.F.D. Distribution of biofilm on internal and external surfaces of upper complete dentures: The effect of hygiene instruction. Gerodontology 2007, 24, 162-168. [CrossRef] [PubMed]

12. Marsh, P.D. Contemporary perspective on plaque control. Br. Dent. J. 2012, 212, 601-606. [CrossRef] [PubMed]

13. Tadeusiewicz, J.; Olas, B. Tlenek azotu i tlenek węgla-dwa ważne gazo transmitery. Kosmos 2014, 63, 543-554.

14. Gdula-Argasińska, J.; Tyszka-Czochara, M.; Paśko, P.; Opoka, W. Rola wolnych rodników w regulacji procesów fizjologicznych. Med. Int. Revuo 2012, 25, 41-46.

15. Pereira, A.C.; Paulo, M.; Araújo, A.V.; Rodrigues, G.J.; Bendhack, L.M. Nitric oxide synthesis and biological functions of nitric oxide released from ruthenium compounds. Braz. J. Med. Biol. Res. 2011, 44, 947-957. [CrossRef] [PubMed]

16. Dai, Z.; Wu, Z.; Yang, Y.; Wang, J.; Satterfield, M.C.; Meininger, C.J.; Bazer, F.W.; Wu, G. Nitric oxide and energy metabolism in mammals. Biofactors 2013, 39, 383-391. [CrossRef] [PubMed]

17. Kasperska-Zajac, A.; Grzanka, A.; Kowalczyk, J.; Wyszyńska-Chłap, M.; Lisowska, G.; Kasperski, J.; Jarząb, J.; Misiołek, M.; Kalarus, Z. Refractory chronic spontaneous urticaria and permanent atrial fibrillation associated with dental infection: Mere coincidence or something more to it? J. Immunopathol. Pharmacol. 2015, 29, 112-120. [CrossRef]

18. Borkar, S.P.; Bhutada, G.; Pandagale, S. Nitric oxide as an inflammatory biomarker in oral and periodontal diseases. Int. J. Oral Health Med. Res. 2016, 3, 76-80.

19. Tripathi, P.; Tripathi, P.; Kashyap, L.; Singh, V. The role of nitricoxide in inŁammatory reactions. FEMS Immunol. Med. Microbiol. 2007, 51, 443-452. [CrossRef]

20. Matsunaga, K.; Kuwahira, I.; Hanaoka, M.; Saito, J.; Tsuburai, T.; Fukunaga, K.; Matsumotog, H.; Sugiurah, H.; Japanese, M.; Pulmonary, J.R.S.A. An official JRS statement: The principles of fractional exhaled nitric oxide (FeNO) measurement and interpretation of the results in clinical practice. Respir. Investig. 2021, 59, 34-52. [CrossRef]

21. Selby, A.; Clayton, B.; Grundy, J.; Pike, K.; Drew, K.; Raza, A.; Kurukulaaratchy, R.; Arshad, S.H.; Roberts, G. Are exhaled nitric oxide measurements using the portable NIOX MINO repeatable? Respir. Res. 2010, 23, 11-43. [CrossRef] [PubMed]

22. Dadas-Stasiak, E.; Jung, A.; Jobs, K.; Kalicki, B. Ocena stężenia tlenku azotu w powietrzu wydychanym u dzieci z alergicznym nieżytem nosa. Pediatr. Med. Rodz 2016, 12, 285-295. [CrossRef]

23. De Laurentiis, G.; Maniscalco, M.; Cianciulli, F.; Stanziola, A.; Marsico, S.; Lundberg, J.O.; Weitzberg, E.; Sofia, M. Exhaled nitric oxide monitoring in COPD using a portable analyzer. Pulm. Pharmacol. Ther. 2008, 21, 689-693. [CrossRef] [PubMed]

24. Mierzejewska, A.; Jodłowska, M.; Kućko, A.; Rybak, K.; Sołtysiak, M.; Sroka, S.; Kalicki, B. Przydatność określania stężenia tlenku azotu w wydychanym powietrzu w ocenie stopnia ciężkości astmy u dzieci. Pediatr. Med. Rodz. 2015, 11, $186-196$.

25. Wiatrak, K.; Morawiec, T.; Rój, R.; Mertas, A.; Machorowska-Pieniążek, A.; Kownacki, P.; Tanasiewicz, M.; Skucha-Nowak, M.; Baron, S.; Piekarz, T.; et al. Oral health of patients treated with acrylic partial dentures using a toothpaste containing bee product. Evid. Based Complement Alternat. Med. 2017. Available online: https://www.hindawi.com/journals/ecam/2017/4034179/ (accessed on 30 January 2021).

26. Niedzielska, I.; Puszczewicz, Z.; Mertas, A.; Niedzielski, D.; Różanowski, B.; Baron, S.; Konopka, T.; Machorowska-Pieniążek, A.; Skucha-Nowak, M.; Tanasiewicz, M.; et al. The influence of ethanolic extract of Brazilian green propolis gel on hygiene and oral microbiota in patients after mandible fractures. Biomed. Res. Int. 2016. [CrossRef]

27. Pisi, R.; Aiello, M.; Tzani, P.; Marangio, E.; Olivieri, D.; Chetta, A. Measurement of fractional exhaled nitric oxide by a new portable device: Comparison with the standard technique, journal of asthma. J. Asthma 2010, 47, 805-809. [CrossRef]

28. Maniscalco, M.; Lundberg, J.O. Hand-held nitric oxide sensor NIOX MINO(R) for the monitoring of respiratory disorders. Expert Rev. Respir. Med. 2010, 4, 715-721. [CrossRef]

29. Rochwerg, B.; Brochard, L.; Elliott Mark, W.; Hess, D.; Hill, N.S.; Nava, S.; Navalesi, P.; Antonelli, M.; Brozek, J.; Conti, G.; et al. Official ERS/ATS clinical practice guidelines: Noninvasive ventilation for acute respiratory failure. Eur. Respir. J. 2017, 50, 1602426. [CrossRef]

30. Kłak, A.; Krzych-Fałta, E.; Samoliński, B. Rola tlenku azotu w stanie zapalnym dróg oddechowych. Alerg. Astma Immun. 2013, 18, 91-96.

31. Heffler, E.; Carpagnano, G.E.; Favero, E.; Guida, G.; Maniscalco, M.; Motta, A.; Paoletti, G.; Rolla, G.; Baraldi, E.; Pezzella, V.; et al. Fractional Exhaled Nitric Oxide (FENO) in the management of asthma: A position paper of the Italian Respiratory Society (SIP/IRS) and Italian Society of Allergy, Asthma and Clinical Immunology (SIAAIC). Multidiscip. Respir. Med. 2020, 15, 36.

32. de Abreu, F.C.; da Silva Júnior, J.L.R.; Rabahi, M.F. The fraction exhaled nitric oxide as a biomarker of asthma control, biomarker insights. Biomark. Insights 2019, 14. [CrossRef]

33. Lundberg, J.O.; Weitzberg, E.; Lundberg, J.M.; Alving, K. Intragastric nitric oxide production in humans: Measurements in expelled air. Gut 1994, 35, 1543-1546. [CrossRef] [PubMed]

34. Kasperski, J.; Wyszyńska, M.; Kustra, S.; Czecior, E.; Misiołek, M.; Kasperska-Zając, A. Does helicobacter pylori infection increase the levels of exhaled nitric oxide? Eur. J. Inflamm. 2013, 11, 279-282. [CrossRef]

35. Ziętkowski, Z.; Ziętkowska, E.; Bodzenta-Łukaszyk, A. Kliniczne znaczenie pomiarów stężenia tlenku azotu w powietrzu wydychanym w chorobach układu oddechowego. Alerg. Astma Immun. 2009, 14, 215-222.

36. Dor-Wojnarowska, A.; Liebhart, J.; Grabowski, M.; Czapla, L.; Grabowski, K.; Panaszek, B. Stężenie tlenku azotu w wydychanym powietrzu u chorych na zapalenie przełyku. Pneumonol. Alergol. Pol. 2011, 79, 272-277.

37. Przybyłowski, T.; Bielicki, P.; Kumor, M. Tlenek azotu w powietrzu wydechowym u chorych na obturacyjny bezdech podczas snu. Pneumonol. Alergol. Pol. 2006, 74, 21-25. 
38. Reher, V.G.; Zenóbio, E.G.; Costa, F.O.; Reher, P.; Soares, R.V. Nitric oxide levels in saliva increase with severity of chronic periodontitis. J. Oral Sci. 2007, 49, 271-276. [CrossRef]

39. Batista, A.C.; Silva, T.A.; Chun, J.H.; Lara, V.S. Nitric oxide synthesis and severity of human periodontal disease. Oral Dis. 2002, 8, 254-260. [CrossRef]

40. Lappin, D.F.; Kjeldsen, M.; Sander, L.; Kinane, D.F. Inducible nitric oxide synthase expression in periodontitis. J. Periodont. Res. 2000, 35, 369-373. [CrossRef]

41. Shibata, K.; Warbington, M.L.; Gordon, B.J.; Kurihara, H.; Van Dyke, T.E. Nitric oxide synthase activity in neutrophils from patients with Localized Aggressive Periodontitis. J. Periodontol. 2001, 72, 1052-1058. [CrossRef]

42. Aurer, A.; Josko, A.; Ivic-Kardum, M.; Aurer, J.; Culo, F. Nitric oxide synthesis is decreased in periodontitis. J. Clin. Periodontol. 2001, 28, 565-568. [CrossRef] [PubMed]

43. Hirose, M.; Ishihiara, K.; Saito, A.; Nakagawa, T.; Yamada, S.; Okuda, K. Expression of cytokines and inducible nitric oxide synthase in inflamed gingival tissue. J. Periodontol. 2001, 72, 590-595. [CrossRef] [PubMed]

44. Panjwani, S.; Bagewadi, A.; Keluskar, V.; Malik, R.; Rai, S.; Misra, D. Estimation and comparisonof levels f Salivary Nitric Oxide in patients with oral lichen planus and controls. Int. J. Prev. Med. 2013, 4, 710-714. [PubMed]

45. İşcan, Y.; Yiğit, U.; Tuğcu Çakmak, B.; Erdoğan, M.; Erdoğan, D.A.; Öner, V.; Taş, M.; Özyazgan, Y. Tear nitric oxide levels in behçet's disease. Medicine 2012, 48, 81. [CrossRef] 